\title{
Modelling the global economic consequences of a major African swine fever outbreak in China
}

\author{
Daniel Mason-D'Croz $1^{1 凶}$, Jessica R. Bogard', Mario Herrero ${ }^{1}$ ', Sherman Robinson'2, \\ Timothy B. Sulser ${ }^{2}{ }^{2}$, Keith Wiebe $\mathbb{(}^{2}$, Dirk Willenbockel ${ }^{3}$ and H. Charles J. Godfray ${ }^{4} 4$
}

\begin{abstract}
African swine fever is a deadly porcine disease that has spread into East Asia where it is having a detrimental effect on pork production. However, the implications of African swine fever on the global pork market are poorly explored. Two linked global economic models are used to explore the consequences of different scales of the epidemic on pork prices and on the prices of other food types and animal feeds. The models project global pork prices increasing by $17-85 \%$ and unmet demand driving price increases of other meats. This price rise reduces the quantity of pork demanded but also spurs production in other parts of the world, and imports make up half the Chinese losses. Demand for, and prices of, food types such as beef and poultry rise, while prices for maize and soybean used in feed decline. There is a slight decline in average per capita calorie availability in China, indicating the importance of assuring the dietary needs of low-income populations. Outside China, projections for calorie availability are mixed, reflecting the direct and indirect effects of the African swine fever epidemic on food and feed markets.
\end{abstract}

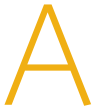

frican swine fever (ASF) is a virulent disease of pigs that orig inated in Africa and has been reported in other continents

from the $1950 \mathrm{~s}^{1}$. It has recently spread into Eastern Asia and was recorded for the first time in China in August 2018. At the time of revising the paper (February 2020), the disease has spread to all mainland provinces and several million pigs have been culled in an effort to halt its spread ${ }^{2,3}$. Industry estimates suggest $150-200$ million pigs (30\% of the Chinese population) have been infected by mid$2019^{3}$, while some press reports indicate that once under-recording is considered the figure may be as high as $50-70 \%$ (refs. ${ }^{4,5}$ ).

ASF is a notifiable haemorrhagic disease caused by an Iridovirus (Asfarviridae) ${ }^{6}$. Its natural hosts in Africa are wild members of the pig family where it is transmitted by soft ticks and does not cause clinical disease ${ }^{7-9}$. Different strains of the virus strike farmed and feral pigs and their European wild boar relatives, with the strain present in China being particularly virulent and causing nearly $100 \%$ mortality $^{10}$. Disease control consists of culling infected herds and imposing strict quarantine procedures; there is no current vaccine or treatment ${ }^{11-13}$. The disease is spread by contaminated products and by the animals themselves. The presence of wild boar populations or free-roaming feral pigs, as found in many areas of China, and the common practice in China of feeding untreated swill to pigs are particular risk factors ${ }^{8}$. There is no direct biological risk to humans from ASF.

It is important to explore the potential consequences of a major epidemic in China and to consider potential ramifications as it spreads. The repercussions could potentially affect not only pork consumption and the incomes of pork producers, but also feed markets, the demand for pork alternatives or substitutes ${ }^{5,14}$ and the diets of consumers in areas directly and indirectly affected by the disease.

This study uses economic modelling of the global food system to examine some of the potential consequences of a major disruption of pig production in China. The modelling approach first considers the direct and a number of indirect consequences of the disruption of the supply of pork on the prices of pork and other food types.
Second, the model is used to explore the sensitivity of the results to different assumptions about supply and demand responses. Five scenarios, where pig production in China remains constant $\left(S^{0}\right)$ or is reduced by $20,40,60$ or $80 \%$ ( $S^{20}$ and so on), are explored.

When we conceived this project, these scenarios spanned the possible range of epidemic severities. At the time of revising this paper (February 2020), it appears the last two scenarios best match the unfolding outbreak, but we present results from the full range of scenarios because these provide information about the effects of possible future less serious epidemics.

\section{Results}

Effects on pork prices, demand, production and trade. China currently (2018) produces about 55 million metric tons (Mt) of pork per year, from more than 700 million slaughtered pigs ${ }^{15}$. Our simulations assume a reduction of pigs that leads to a decline in pork production in China of between 10 and $40 \mathrm{Mt}$ in the four scenarios representing increasingly severe ASF epidemics (Fig. 1a). This represents cuts of $9-34 \%$ in global production $(120 \mathrm{Mt}$ in 2018) compared to a reference scenario without an ASF epidemic (Fig. 1a and Supplementary Table 1). This decline in production would lead to increases in world pork prices of $17-85 \%$ (Fig. 1b). For $S^{60}$ and $S^{80}$, pork prices rise above beef prices, a major inversion of past price trends for the two commodities last observed in $1996^{16}$, when bovine spongiform encephalopathy was linked to CreutzfeldtJacob disease and led to a sharp decline in beef demand ${ }^{17,18}$.

Higher pork prices drive down pork demand in all regions, with average global per capita demand declining by $0.7-2.4 \mathrm{~kg} \mathrm{yr}^{-1}(4-16 \%)$ (Fig. 1c and Supplementary Table 2). In China, the percentage reduction is slightly smaller than the global average (3-13\%) although the actual drop in demand $\left(1.4-5.3 \mathrm{~kg} \mathrm{yr}^{-1}\right)$ is above the global average. Much of the global decline (60\%) happens outside China with the greatest effects (for $S^{80}$ ) observed in Europe $\left(7.9 \mathrm{~kg} \mathrm{yr}^{-1}\right)$, with notable drops in North America $\left(4.5 \mathrm{~kg} \mathrm{yr}^{-1}\right)$, Latin America $\left(2.4 \mathrm{~kg} \mathrm{yr}^{-1}\right)$ and the rest of East Asia and Pacific $\left(2.2 \mathrm{~kg} \mathrm{yr}^{-1}\right)$.

${ }^{1}$ Commonwealth Scientific and Industrial Research Organisation (CSIRO), St Lucia, Queensland, Australia. ${ }^{2}$ Environment and Production Technology Division, International Food Policy Research Institute (IFPRI), Washington DC, USA. ${ }^{3}$ nnstitute of Development Studies at the University of Sussex, Brighton, UK. ${ }^{4}$ Oxford Martin School \& Department of Zoology, University of Oxford, Oxford, UK. 凶e-mail: Daniel.Mason-D'Croz@csiro.au 


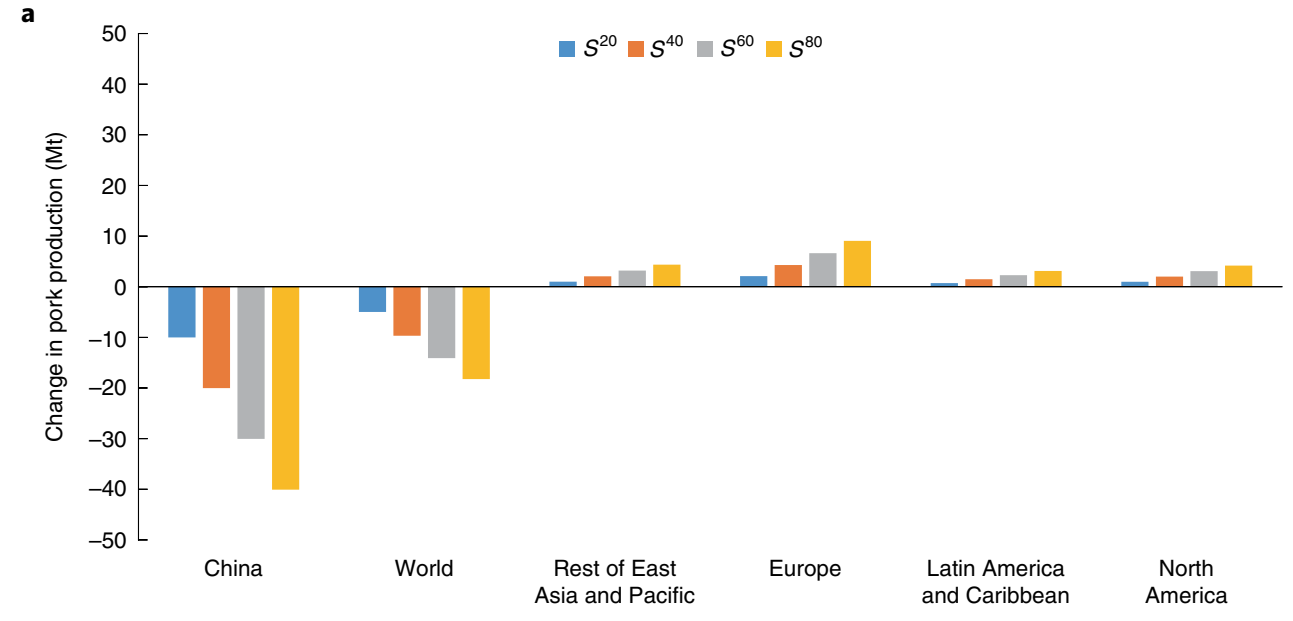

b
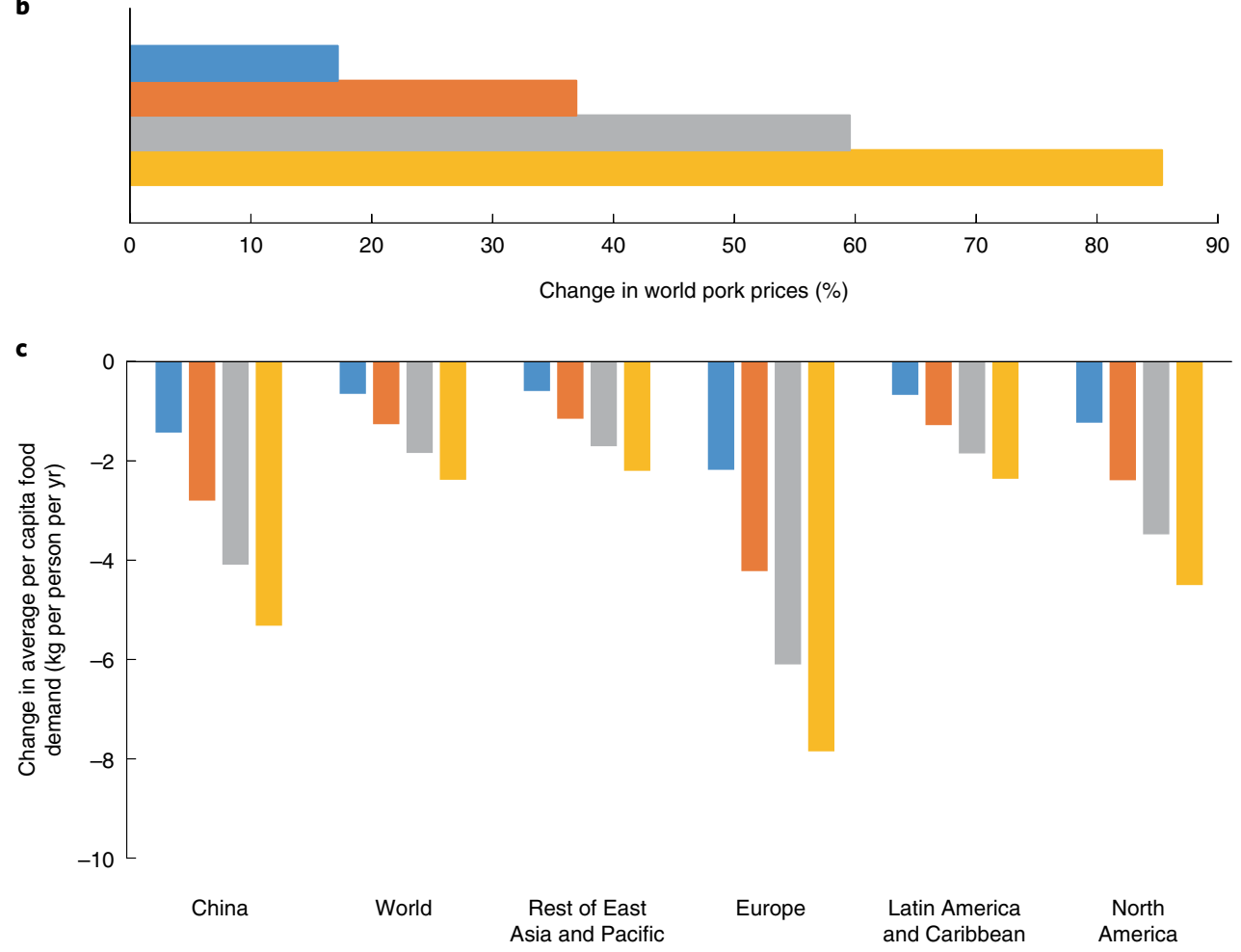

Fig. 1 | Summary of changes from the reference scenario in pork markets in China and selected regions. a-c, Changes in pork production in China and selected regions (a), world pork prices (b) and average per capita food demand in China and selected regions (c).

Higher pork prices spur more production (5-22 Mt) in regions outside China. This response makes up for about half of the losses in China so that overall global production falls by only $5-18 \mathrm{Mt}$ (4-16\%). Europe, the rest of East Asia and Pacific, North America and Latin America are the regions that contribute the most in this global response with increases in pork production of $6.6,4.4,4.2$ and $3.1 \mathrm{Mt}$, respectively.

The reference scenario assumes own-price elasticities based on historical trends and which vary from country to country. To explore uncertainty in how sensitive consumers would be to changes in pork prices, we implemented all scenarios under elasticities half and double the reference assumption. Global pork production and pork prices are negatively correlated with this elasticity (Supplementary Figs. 1 and 2), effects that would be stronger if the changes were applied globally, not just in China.
China is the world's largest pork importer and has seen steady growth in imports over the past decade ${ }^{19}$. Currently, China imports account for about $5 \%$ of domestic demand ${ }^{15}$, as China has tended to encourage feed imports to achieve greater self-sufficiency of meat production ${ }^{19,20}$. The changes described in Fig. 1 suggest that trade will play an important buffering role in reducing the shock to Chinese consumers, albeit at the expense of pork consumers elsewhere. Pork imports into China increase by $8-32 \mathrm{Mt}$. The regions highlighted in Fig. 1 that see the largest increases in production as well as declines in per capita demand are the primary sources of China's additional imports, as pork in these markets gets reallocated to respond to the shock in China.

Knock-on effects on other commodities. Higher pork prices will not only impact consumers and producers of pork. They will also have secondary effects as consumers substitute pork with relatively 
cheaper alternative food types (for example, other meats and plantbased alternatives). Changes in food prices also spur the reallocation of resources in the agricultural sector in response to changing demand patterns. Key inputs to the pork sector in China are reallocated to other uses, whereas the pork sector in other regions takes a larger share of feed inputs as they expand to respond to increased demand for imports into China. This could impact the historical preference in China for grain imports over meat imports ${ }^{19,20}$, at least in the short run until livestock value chains adjust and recover.

As consumers shift to pork substitutes, global production increases to meet this demand (Fig. 2a). However, their prices are projected to rise, which reflects limitations in animal value chains to quickly increase production. Note that these price changes are considerably smaller than those observed for pork (Fig. 1), with beef and poultry seeing price rises of $1.5-6.0 \%$ and $1.6-6.7 \%$, respectively; global production increases by up to $0.1 \mathrm{Mt}$ for beef and $0.4 \mathrm{Mt}$ or poultry (mostly in North and South America) in the case of the most severe epidemic. The ASF epidemic in China causes major disruption to livestock value chains in China and abroad, forcing feed markets to adjust. Figure $2 b, c$ summarizes these spillover effects for key pork substitutes and feed inputs to the livestock sector in China and globally. Changes in feed inputs may negatively or positively affect animal productivity, but we do not model these indirect effects here.

Larger disruptions are seen in feed markets than are observed in global food demand (Fig. 2a) as lower pork production in China reduces the demand for feed crops used in the pig meat industry. Globally, this reduction is partially offset by increased pork production in other regions and increased beef and poultry production both in China and abroad. Nevertheless, the price declines observed for key feed inputs (maize, soybean meal and sweet potatoes) are similar in size to the increases for meat substitutes. In the worst scenario $\left(S^{80}\right)$, maize and soybean meal prices decline by $5 \%$ and $2 \%$, respectively. Sweet potatoes, another important feed input into the pork sector ${ }^{21}$, see the largest price declines of nearly $15 \%$ in $S^{80}$, due to limited domestic and global capacity to use additional sweet potatoes. These price rises may be ameliorated if other uses for sweet potato such as bioethanol production emerge in China. The increase in production of livestock products outside China leads to a substantial reallocation of feed globally. Demand for maize for feed in China declines by as much as $47 \mathrm{Mt}$ compared to the reference scenario. Globally for the same scenario, maize feed demand declines by only $11 \mathrm{Mt}$, with the majority of maize previously destined for the Chinese livestock sector being reallocated to livestock production in other countries. Soybean meal sees a similar trend, whereas the deficit in sweet potato demand is not as readily absorbed by increased livestock production in other regions, explaining the much larger price declines. Price rises for other globally important feeds (wheat and barley) are also observed. These price rises are driven by increased demand for both throughout the world, but particularly in Europe where wheat and barley are disproportionately used in the livestock sector.

The changes in demand for different feedstocks are reflected in shifts in agricultural trade patterns. The most dramatic is a marked decrease in exports of maize from North America. This maize is redirected to support livestock sectors in North America, although there is also an increase in maize exports to Africa (and of sweet potato from China), which affects food security and welfare as discussed below.

Effects on food and nutrition security. We estimate the sum of the spillover effects on different components of people's diets and their effects on calorie consumption. Higher prices for meat and those cereals that serve as animal feeds (for example, wheat) lead to declines in calorie availability in most regions (Fig. 3a). The projected changes in food prices increase food expenditure in China

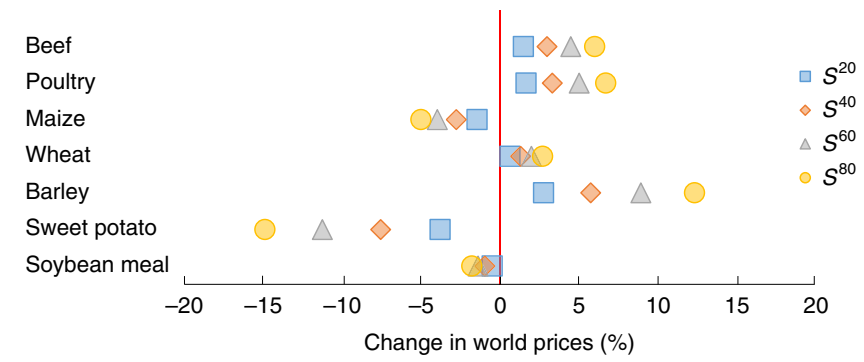

b

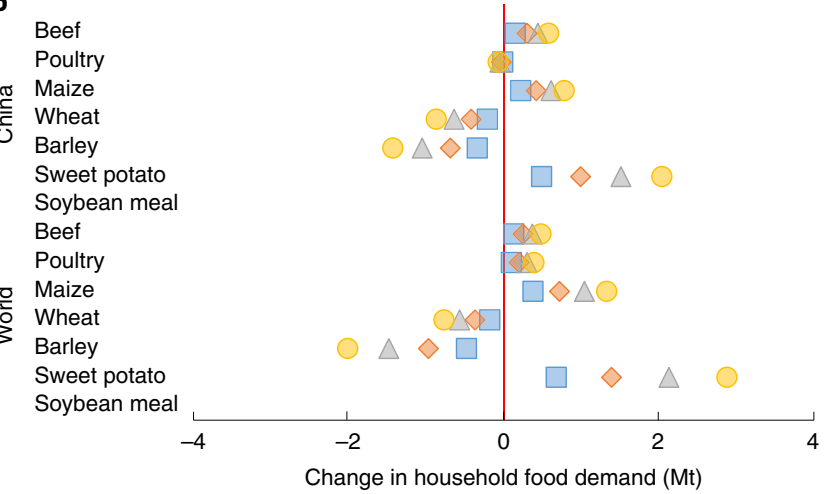

C

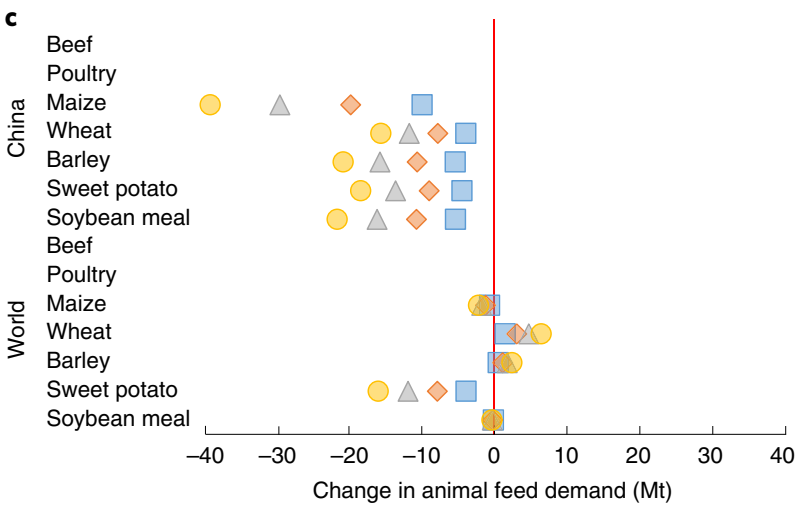

Fig. 2 | Summary of changes from the reference scenario in selected commodity markets in China and globally. a-c, Changes in world prices for selected commodities (a), household food demand (b) and animal feed demand (c).

(as a share of average income in the reference scenario) by as much as $9 \%$ in the most severe scenario. This increase leads to the average per capita calorie availability in China declining by more than $50 \mathrm{kcal}$ per day or $1.6 \%$ of the reference scenario. Aside from China, we see many countries in East and Southeast Asia as well as Europe with declines in calorie availability of more than $1 \%$. In high-income countries where baseline calorie availability is already high, such declines will tend not to have negative health impacts. However, in middle-income countries in Southern and Eastern Europe (for example, Poland and Romania), rising food prices may be of greater concern (Fig. 3b). In East and Southeast Asia, a similar pattern can be seen with higher-income East Asian countries able to absorb the reduction in calories, while the effects in lower-income countries such as Vietnam and the Philippines are of greater concern. The largest absolute change in hunger is found in India (more than 2 million additional people at risk of hunger) and is driven primarily by the secondary price impacts, particularly the increase in the price of wheat, which is an important food staple.

Several countries, particularly in Eastern and Southern Africa and Central America, see an increase in calorie availability. In these 
countries, maize is a dietary staple and they benefit from the lower prices caused by reduced demand for maize as an animal feed. However, this picture is complicated by the preference of consumers in these countries for white rather than yellow maize, which while not uniform across the whole region can be observed by price premiums for white maize ${ }^{22,23}$. Internationally and domestically, white and yellow maize prices tend to track each other; nevertheless, there is evidence that local and global markets are not well integrated, and that transmission of world prices locally is muted and often with a time $\operatorname{lag}^{24,25}$. Eastern and Southern Africa also consume a considerable amount of sweet potatoes and obtain a further benefit from the large price declines in this crop. As for maize price transmissions, there is reason to be skeptical of these gains, given shallow international sweet potato markets. Nevertheless, both China and Africa are net exporters to Europe ${ }^{15}$, and increased availability of sweet potatoes for export could displace some African exports, increasing domestic supply in the region. Overall, the number of people at risk of hunger in sub-Saharan Africa may decline by more than half a million people in the most severe ASF scenario. However, while countries such as the Democratic Republic of the Congo and Tanzania are beneficiaries, those such as Mozambique and Ethiopia would see increases in the population at risk of hunger (Fig. 3b). These projections of varying effects on different countries should be treated as indicative-further analysis considering the national dietary and cultural context, as well as integration between local, regional and international markets, is warranted.

The ASF epidemic may also affect dietary diversity and nutrient intake, particularly in China, with negative health implications (Table 1). Further details are given in the Supplementary Notes but, in particular, the model projects possible reductions in the $\mathrm{B}$ vitamins and zinc. Among macronutrients, the projections show a relatively large reduction in total and saturated fat consumption, which may in some people affect their intake of critical fatsoluble vitamins.

Demand for food is relatively inelastic, so the production shock in Chinese pig production tends to increase global food expenditures. In the absence of any countervailing intervention by governments, consumers will be relatively worse off, especially in countries and regions where pork is a major part of the diet. As the International Model for Policy Analysis of Agricultural Commodities and Trade (IMPACT) is a partial equilibrium model, it cannot be used to explore the effect of changes in prices and production on overall household income. To begin to investigate the effect on household incomes and changes in welfare, we use the output from IMPACT as input to the GLOBE computable general equilibrium model (described above). We found that household welfare in China declined by between 0.12 and $0.78 \%$ for $S^{20}$ to $S^{80}$, with household income declining by 0.3 to $1.8 \%$, respectively (see also Supplementary Table 3). For the worst-case ASF scenario, this is a socio-economically important and perhaps politically relevant decline.

Outside China, we find that only a few regions benefit from increased commodity prices (Fig. 4). These are major meatexporting regions, with the largest gains $0.01-0.09 \%$ observed in high-income countries in Oceania (Australia and New Zealand). Most other regions see small declines in welfare. In all cases, these shifts are many orders smaller than those observed in China.

\section{Discussion}

Approximately half of global pig production occurs in China. The presence of a disease as deadly as ASF in East Asia will have major ramifications for the global food system and food security ${ }^{6}$. Our projections of the effects of a major production shock in the Chinese pig industry using a global partial equilibrium economic model of the food sector provide an indication of the capacity of the national and global food system to absorb the perturbation without large effects on prices and consumption. This resilience comes about through international trade and consumers switching to non-pork foods. The effects of an ASF outbreak in China are not limited to China, but are experienced in other countries and affect other food types. While we modelled a shock and a response that occurred within a year, delays in restocking and an epidemic that lasts for a greater period of time are likely to lead to more severe effects.

Recent data on pork prices in China show increases of the order of 50\% during 2019 (Fig. 5), which may have contributed to inflation in China recently exceeding government targets. These are consistent with our projections, although we think it is too early to do a formal comparison and validation of the model. There is still considerable uncertainty about the extent of the epidemic, and some of the economic data are still preliminary.

It is important to explore whether this conclusion is a consequence of model assumptions that may not reflect real-world food systems accurately. Models such as IMPACT assume that markets regularly equilibrate. If there are frictions or disruptions, so that markets clear more slowly or trading flows adjust less rapidly, then the initial effects of the outbreak may be larger and more spatially contained. IMPACT also tends to overestimate the degree to which domestic markets in low-income countries are tied to world markets and hence some of the effects of the ASF outbreaks on sub-Saharan countries may be less than projected ${ }^{24-26}$. In addition, IMPACT uses data from the Food and Agriculture Organization and these are based on national statistics, which have been found in some studies to be inconsistent, particularly with respect to pork ${ }^{27}$.

Several aspects of real-world food systems may influence the effects of an ASF outbreak. First, the release of frozen meat in 2019 is thought to have tempered pork price rises in China ${ }^{5}$, and this approach could be taken again. Such policy decisions would probably be captured by a simple reduction in the size of the production shock in proportion to the amount of stocks released. Pork production and consumption vary across the country ${ }^{28}$. Per capita consumption is lowest in the north and east and highest in the south and west: the region with least consumption is the western province of Xinjiang $\left(3.8 \mathrm{~kg} \mathrm{yr}^{-1}\right)$, with its large Muslim population, and highest in the southern provinces of Sichuan and Chongqing $\left(>30 \mathrm{~kg} \mathrm{yr}^{-1}\right)$. Since the outbreak began, the Chinese authorities have introduced and sometimes relaxed different regulations about inter-province pig trade that will have affected price transmission and local prices, but these are not modelled here.

Second, it is possible that the presence of ASF affects not only supply but also demand. In previous outbreaks of livestock diseases, demand of affected commodities was reduced in part due to a loss in trust in the quality and safety of the commodities ${ }^{29,30}$. There is evidence of this already occurring in China ${ }^{5}$. This impact can linger beyond the initial outbreak and can take some time (a decade or more) before consumers fully return to previous levels.

Third, governments often respond to production shocks by imposing tariffs or export restrictions. These policies are typically motivated by a wish to protect local producers or consumers (or a political imperative to be seen to be doing something), with their effectiveness depending on trading partners. Import restrictions on live animals or animal products are likely to be introduced as quarantine measures. In general, trade restrictions will tend to reduce the capacity of the global food system to buffer production shocks, although genuine quarantine measures can help contain the disease.

Finally, the current ASF outbreak is occurring at a time of tension in global trading relationships, especially between China and a major source of pork imports, the United States. Tariffs on US pork imports into China have recently increased from $12 \%$ to $62 \%$, although this has not disincentivized some major purchases ${ }^{31}$. In July 2019 , net tariffs were at $81 \%$, although the politics are fluid, which adds an additional layer of geopolitical uncertainty to the way the global food system will be affected by the disease outbreak. 

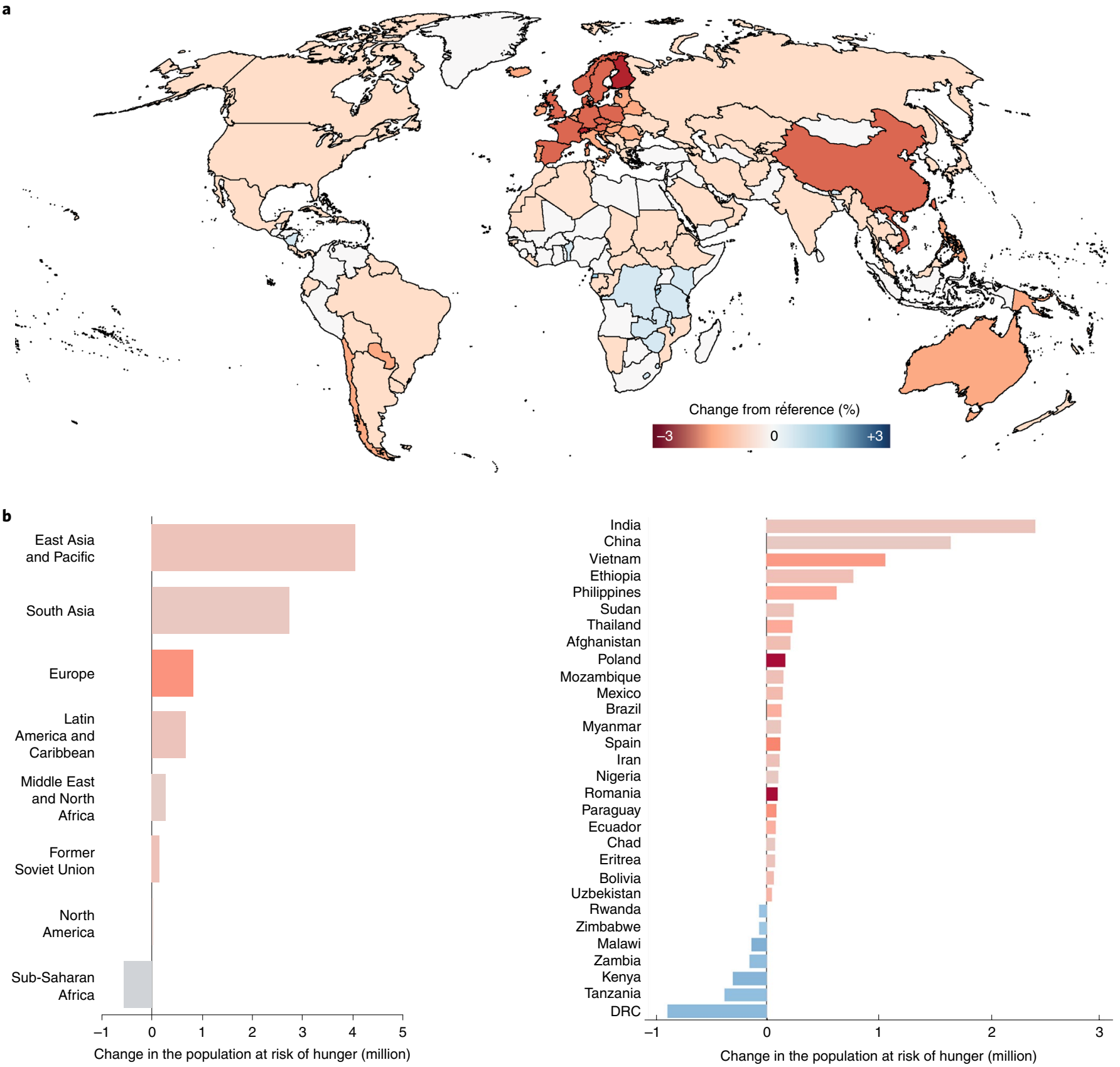

Change from reference (\%)

Fig. 3 | Effect of the ASF epidemic on calorie availability and risk of hunger. a, Percentage change from the reference scenario in average calorie availability in $S^{80} . \mathbf{b}$, Changes in the population at risk of hunger in absolute (bar length) and relative (colour scale) terms by region (left) and selected countries (right) in $S^{80}$ compared to the reference. DRC, Democratic Republic of the Congo.

The outbreak of the coronavirus (COVID-19) that is developing as we revise the paper (February 2020), and which affects humans (and conceivably pigs), adds another level of uncertainty that is as yet impossible to assess, although possibly it may have reversed a small decline in pork prices at the end of 2019 (Fig. 5).

Since the beginning of the project, the outbreak has expanded rapidly to other countries. ASF has now been recorded in 2019 from Mongolia (January), Vietnam (February), Cambodia (April), North Korea (May), Laos (June), Philippines (July), Myanmar (August), Timor-Leste (September) and South Korea (November) and may be in Indonesia (November). Further mod- elling of a broader epidemic in Asia would be informative, as well as in Europe, which has suffered a number of smaller-scale outbreaks. In Europe, the pig industry is more intensive and more vertically integrated ${ }^{32}$, in part due to challenges from other diseases, and containment should be easier compared to Asia with its large smallholder sector ${ }^{33}$. Nevertheless, the disease is causing major concern in Europe, with Denmark building a fence along its southern border to prevent wild boar entering from Germany. A serious ASF outbreak in Europe could undermine the Common Agricultural Policy and "dramatically shake European identity and cohesion" ${ }^{34}$ 
Table 1 | Changes in selected macronutrients and micronutrients in China

\begin{tabular}{|c|c|c|c|c|c|c|c|}
\hline & \multirow[b]{2}{*}{ Nutrients } & \multirow[b]{2}{*}{ China $A^{a}$} & \multirow[b]{2}{*}{ RNS $^{b}$} & \multicolumn{4}{|c|}{$\begin{array}{l}\text { Percentage change in nutrient intake in } 2020 \text { under } \\
\text { the four ASF scenarios }\end{array}$} \\
\hline & & & & $S^{20}$ & $S^{40}$ & $S^{60}$ & $S^{80}$ \\
\hline \multirow[t]{5}{*}{ B vitamins } & Folate $\left(B 9, \mu g^{c}\right)$ & 1.1 & 403 & 0 & -0.1 & -0.1 & -0.1 \\
\hline & Niacin $\left(B 3, \mathrm{mg}^{\mathrm{d}}\right)$ & 1.8 & 27 & -0.4 & -0.8 & -1.3 & -1.6 \\
\hline & Riboflavin (B2, mg) & 1.4 & 2 & -0.3 & -0.7 & -1 & -1.3 \\
\hline & Thiamin (B1, mg) & 1.8 & 2 & -0.6 & -1.2 & -1.8 & -2.3 \\
\hline & Vitamin B6 (mg) & 2.6 & 3 & -0.3 & -0.6 & -0.8 & -1.1 \\
\hline \multirow[t]{4}{*}{ Minerals } & Iron (mg) & 1 & 21 & -0.1 & -0.2 & -0.4 & -0.5 \\
\hline & Phosphorus (mg) & 2.6 & 1,925 & -0.2 & -0.5 & -0.7 & -0.9 \\
\hline & Potassium (g) & 1 & 5 & -0.1 & -0.2 & -0.4 & -0.5 \\
\hline & Zinc (mg) & 1.2 & 17 & -0.4 & -0.8 & -1.1 & -1.5 \\
\hline \multirow{3}{*}{ Fat-soluble vitamins } & Vitamin $D\left(\mu g^{f}\right)$ & 0.5 & 1 & 0.1 & 0.2 & 0.2 & 0.3 \\
\hline & Vitamin E (mgg) & 0.7 & 11 & 0 & -0.1 & -0.1 & -0.1 \\
\hline & Vitamin K $(\mu \mathrm{g})$ & 4.5 & 299 & 0 & -0.1 & -0.1 & -0.1 \\
\hline
\end{tabular}

\begin{tabular}{|c|c|c|c|c|c|}
\hline & & $S^{20}$ & & 60 & $S^{80}$ \\
\hline & China & -0.12 & -0.28 & -0.49 & -0.78 \\
\hline & Other East Asia & 0.00 & 0.00 & -0.01 & -0.01 \\
\hline East Asia and Pacific & & & & & \\
\hline & High-income Asia & 0.00 & -0.01 & -0.01 & -0.02 \\
\hline & High-income Oceania & 0.01 & 0.03 & 0.06 & 0.09 \\
\hline & India & 0.00 & 0.00 & 0.00 & 0.00 \\
\hline & Other South Asia & 0.00 & 0.00 & 0.00 & 0.00 \\
\hline Latin America and & Central America & 0.00 & 0.00 & 0.00 & -0.01 \\
\hline Caribbean & South America & 0.00 & 0.00 & 0.00 & 0.00 \\
\hline & West Africa & 0.00 & -0.01 & -0.01 & -0.02 \\
\hline Sub-Saharan Africa & East Africa & 0.00 & -0.01 & -0.01 & -0.02 \\
\hline & Southern Africa & 0.00 & 0.00 & 0.00 & 0.01 \\
\hline Middle East and North & h Africa & 0.00 & -0.01 & -0.01 & -0.02 \\
\hline Europe & & 0.00 & 0.00 & 0.00 & 0.00 \\
\hline North America & & 0.00 & 0.00 & 0.00 & 0.01 \\
\hline Former Soviet Union & & 0.00 & -0.01 & -0.01 & -0.02 \\
\hline
\end{tabular}

Fig. 4 | Percentage change in average household welfare by region and scenario. The heat chart uses two colour schemes reflecting the fact that the impacts in China are ten times higher than in other regions. Changes in China are in red and range from 0 (white) to $-1 \%$ (red). A different scale is used for other regions where blue reflects welfare improvements (up to $0.1 \%$ ) and orange reflects welfare reductions (up to $-0.1 \%$ ).
An ASF outbreak will have both macroeconomic and welfare economic consequences. Agriculture currently makes up 7-8\% of Chinese gross domestic product (GDP) ${ }^{35}$ with the pork sector contributing $10-15 \%$ of gross agricultural value added ${ }^{15}$. The pork sector is probably worth more than US $\$ 100$ billion and the worst outbreaks we simulated would reduce Chinese GDP by approximately $1 \%$. For context, this reduction is a little less than the effect of the 2008 Sichuan earthquake, but of the order of 20 times greater than recent avian flu outbreaks or the SARS (severe acute respiratory syndrome) outbreak centred on southern China in 2002-2003. In the same regions, the early 2000s avian flu outbreak depressed Vietnam GDP by $0.3-1.5 \%$ (US $\$ 0.1-0.6$ billion) ${ }^{36}$. Further analysis of the costs of the epidemic, in particular of mass culling, and of alternative mitigation strategies would be welcome.

Although analysis with the GLOBE model suggests that average household incomes will decline by less than $2 \%$ in the worst case, predominantly smallholder farmers in the lower deciles of the income distribution will be affected by $\mathrm{ASF}^{37}$. Some farmers will be insured against epidemic risk, but the majority will have no or inadequate insurance. Thus, it is likely that the government would need to provide income support. Furthermore, the impacts on the mental health of farmers and their families are likely to be substantial.

China will probably import more pork and less pig feed with consequences for trading partners. Pork producers in exporting countries will benefit, although consumers will experience higher prices in domestic markets. Feed producers will look for new markets, resulting in increased exports of commodities such as maize and sweet potato to emerging economies in sub-Saharan Africa and elsewhere. In this case, there is a risk that local agriculture may be undermined, especially if exports are supported by direct and indirect subsidies and other market distortions.

In the longer term, the current ASF outbreak will spur investment in research and innovation with the possibility of vaccine development ${ }^{13}$. A less optimistic possibility is that the disease 


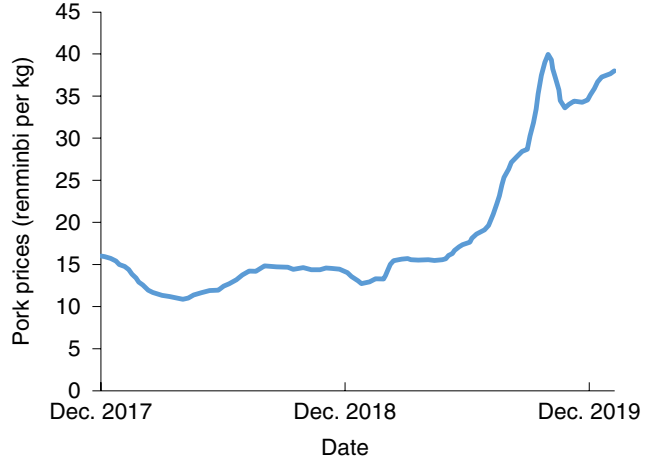

Fig. 5 | Changes in Chinese pork prices from 31 December 2017 to 6 February 2020. The data are from the Professional Pig Community (https://www.pig333.com/).

becomes endemic with periodic resurgences buffeting the food system. This possibility would reduce the attractiveness of pig production for investment and tend to increase food prices. Consumers could respond by switching to meat substitutes, chicken or ruminant meats. Given the different consequences for human health and the environment of the production and consumption of these different food types, there are possibilities for both positive and negative indirect effects of continuing ASF outbreaks.

\section{Methods}

Model. We studied the effect of ASF in China on food system dynamics using two linked global models: IMPACT developed by the International Food Policy Research Institute ${ }^{38,39}$, and a dynamic version of $\mathrm{GLOBE}^{40}$. These two models were used to assess the potential effects on the broader global economy and average incomes across regions and countries that are linked to China through international trade. The IMPACT model has been used to explore other supply shock scenarios (for example, the effects of a major disease of rice in Southeast Asia ${ }^{41}$ and extreme weather events affecting particular regions ${ }^{42}$ or the global food system ${ }^{43}$ ).

Briefly (see Supplementary Information for a fuller explanation), IMPACT is a partial equilibrium economic model that represents the production and consumption of 62 agricultural commodities in 158 political units (which are composed of 1 or more sub-regions where political units encompass several water basins). Consumer diets are determined by income and food prices summarized by functions (with constant price elasticities) describing how they affect demand; while producer behaviour is determined analogously by commodity prices and input costs. Population and income are treated as exogenous, with crop yield growth rates having both exogenous and endogenous components. IMPACT is linked to crop and hydrological models (that can themselves be driven by global climate models) to determine changing yield patterns. Different countries are linked by international trade and IMPACT simulates the operation of the global economy, finding world prices for all included commodities that clear international markets. IMPACT does not directly project future diets, but dietary patterns and calorie intake can be estimated under different scenarios and compared with WHO (World Health Organization) guidelines for a healthy diet (assumed to be $\sim 2,500 \mathrm{kcal}$ for men and $\sim 2,000 \mathrm{kcal}$ for women) as was done in Springmann et al. ${ }^{44}$.

The IMPACT model includes only agricultural goods and markets and does not incorporate links between agriculture and the rest of the economy. To capture these links, we use a separate global model (GLOBE) that operates at the level of national economies, incorporating production and demand for all commodities, and trade between countries. This model simulates the operation of commodity and factor markets in all countries and finds equilibrium commodity prices and wages of factors of production that clear both domestic and world markets together. This dynamic computable general equilibrium (CGE) model is calibrated with a global dataset maintained by the Global Trade Analysis Project at Purdue University ${ }^{45}$.

In our analysis, the IMPACT model is used to determine the effects of a shock on the agricultural sectors. The results are then 'soft linked' to the GLOBE CGE mode $^{46}$, which is used to analyse the effects of the changes in agriculture on the rest of the economy, tracing the direct and indirect links between the agricultural and non-agricultural sectors. The CGE model captures links between commodity markets and factor markets, showing how a shock in agriculture affects incomes, supply, demand and prices across the economy.

Scenarios. Our main analysis is a comparison of a reference scenario with a series of alternative scenarios in which we assume that the number of pigs in China is reduced by $20,40,60$ and $80 \%$ in a single year. In the face of great uncertainty (at the time the project was conceived) about the possible severity of an epidemic, we choose these five alternatives to span a full range of possibilities. The reduction includes pigs killed by the disease and those slaughtered (but not consumed) to prevent the spread of the epidemic. Pork prices in China cycle with a period of approximately four years ${ }^{47}$, which seems to be associated with inaccurate expectations about future profits. We think it likely that the appearance of the epidemic reset profit expectations and we make no attempt to model the cycle. There has been a reduction in China's pig herd (although less, only 2\%, in pigs slaughtered) since about 2013 due to tightening environmental regulations, but this has been relatively gradual and very different from the dramatic declines beginning in 2018 .

The assumed income elasticity is 0.18 , which is broadly consistent with income elasticities estimated by the US Department of Agriculture ${ }^{48}$ ( 0.24 for urban and 0.13 for rural households). IMPACT's default own-price elasticity of demand for pork is -0.23 . This is within the range of price elasticities reviewed by Chen et al. although on the inelastic side as IMPACT elasticities are calibrated for long-run as opposed to short-run behaviour. This elasticity represents an average Chinese consumer and is a simplification of the diversity of demand outcomes (preferences, incomes, available food budgets and prices) within the country. This simplification allows us to estimate average changes but will not allow us to capture some of the potential distributional and compositional effects that might occur from production and price shocks that would impact different consumers to varying extents. We explore the sensitivity of the results to the value of the own-price elasticity for pork by halving or doubling the assumed value, which we expect to include the likely range of uncertainty about that parameter.

Reporting Summary. Further information on research design is available in the Nature Research Reporting Summary linked to this article.

\section{Data availability}

Full documentation for IMPACT and GLOBE is available at http://ebrary.ifpri.org/ cdm/ref/collection/p15738coll2/id/129825 and http://ebrary.ifpri.org/cdm/ref/ collection/p15738coll2/id/132757, respectively. Model output from this study can be found in the Mendeley Data repository at https://doi.org/10.17632/zgrngg5hp5. Source data are provided with this paper.

Received: 23 August 2019; Accepted: 4 March 2020; Published online: 17 April 2020

\section{References}

1. Cwynar, P., Stojkov, J. \& Wlazlak, K. African swine fever status in Europe. Viruses 11, 310 (2019)

2. African Swine Fever Situation in Asia Update (FAO, 2019); http://www.fao.org/ ag/againfo/programmes/en/empres/ASF/situation_update.html

3. McCracken, C., Pan, C. \& Sherrard, J. Rising African swine fever losses to lift all protein boats. Rabobank (April 2019); https://research.rabobank.com/ far/en/sectors/animal-protein/rising-african-swine-fever-losses-to-lift-allprotein.html

4. Gu, H. \& Daly, T. China has shown 'shortcomings' in bid to contain African swine fever. Reuters (3 July 2019); https://uk.reuters.com/article/us-chinaswinefever-policy/china-has-shown-shortcomings-in-bid-to-contain-africanswine-fever-cabinet-idUKKCN1TY15E

5. Pan, C. African swine fever affects China's pork consumption. Rabobank (June 2019); https://research.rabobank.com/far/en/sectors/animal-protein/ african-swine-fever-affects-china-s-pork-consumption.html

6. Beltrán-Alcrudo, D., Arias, M., Gallardo, C., Kramer, S. \& Penrith, M. L. African Swine Fever: Detection and Diagnosis - A Manual for Veterinarians FAO Animal Production and Health Manual No. 19 (Food and Agriculture Organization of the United Nations, 2017)

7. Penrith, M. L. \& Vosloo, W. Review of African swine fever: transmission, spread and control. J. S. Afr. Vet. Assoc. 80, 58-62 (2009).

8. Costard, S., Mur, L., Lubroth, J., Sanchez-Vizcaino, J. M. \& Pfeiffer, D. U. Epidemiology of African swine fever virus. Virus Res. 173, 191-197 (2013).

9. Sanchez-Vizcaino, J. M., Mur, L., Gomez-Villamandos, J. C. \& Carrasco, L. An update on the epidemiology and pathology of African Swine Fever. J. Comp. Pathol. 152, 9-21 (2015).

10. Zhou, L., Yu, E. Y. W., Wang, S. J. \& Sun, C. P. African swine fever epidemic in China. Vet. Rec. 184, 713-713 (2019).

11. Costard, S. et al. African swine fever: how can global spread be prevented? Phil. Trans. R. Soc. B 364, 2683-2696 (2009).

12. Barasona, J. A. et al. First oral vaccination of Eurasian wild boar against African swine fever virus genotype II. Front. Vet. Sci. 6, https://doi. org/10.3389/fvets.2019.00137 (2019).

13. Sanchez, E. G., Perez-Nunez, D. \& Revilla, Y. Development of vaccines against African swine fever virus. Virus Res. 265, 150-155 (2019).

14. Polansek, T. China makes major U.S. pork purchase despite steep import tariffs, as hog virus takes toll. Reuters (14 March 2019); https://uk.reuters. 
com/article/us-usa-china-trade-pork/china-makes-major-u-s-pork-purchasedespite-steep-import-tariffs-as-hog-virus-takes-toll-idUKKCN1QV2MR

15. Food and Agriculture Commodities Production (FAOSTAT, 2019); http:// faostat.fao.org/default.aspx

16. IMF Primary Commodity Prices (IMF, 2017); https://www.imf.org/external/ $\mathrm{np} / \mathrm{res} / \mathrm{commod} /$ index.aspx

17. Caskie, P., Moss, J. E. \& Davis, J. The beginning of the end or the end of the beginning for the BSE crisis? Food Policy 23, 231-240 (1998).

18. Taha, F. A. \& Hahn, W. F. The impact of BSE on U.S. exports of beef and pork. Agribusiness 30, 5-16 (2014).

19. Luo, Z. J. \& Tian, X. Can China's meat imports be sustainable? A case study of mad cow disease. Appl. Econ. 50, 1022-1042 (2018).

20. Yu, W. S. \& Cao, L. J. China's meat and grain imports during 2000-2012 and beyond: a comparative perspective. J Integr. Agr. 14, 1101-1114 (2015).

21. Peters, D. Sweet Potato and Pigs: Traditional Relationships, Current Practices and Future Prospects (Nova Science, 2010).

22. Ekpa, O., Palacios-Rojas, N., Kruseman, G., Fogliano, V. \& Linnemann, A. R. Sub-Saharan African maize-based foods: technological perspectives to increase the food and nutrition security impacts of maize breeding programmes. Glob. Food Secur. 17, 48-56 (2018).

23. De Groote, H. \& Kimenju, S. C. Consumer preferences for maize products in urban Kenya. Food Nutr. Bull. 33, 99-110 (2012).

24. Baffes, J., Kshirsagar, V. \& Mitchell, D. What Drives Local Food Prices? Evidence from the Tanzanian Maize Market Policy Research Working Paper no. WPS 7338 (World Bank, 2015).

25. Rudolf, R. The impact of maize price shocks on household food security: panel evidence from Tanzania. Food Policy 85, 40-54 (2019).

26. Abidoye, B. O. \& Labuschagne, M. The transmission of world maize price to South African maize market: a threshold cointegration approach. Agr. Econ. 45, 501-512 (2014)

27. Yu, X. H. \& Abler, D. Where have all the pigs gone? Inconsistencies in pork statistics in China. China Econ. Rev. 30, 469-484 (2014).

28. Yan, B. J., Yan, J. J., Shi, W. J. \& Li, Y. X. Study on the comprehensive comparative advantages of pig production and development in China based on geographic information system. Clean Technol. Environ. Policy 22, 105-117 (2019).

29. Mu, J. H. E., McCarl, B. A., Hagerman, A. \& Bessler, D. Impacts of bovine spongiform encephalopathy and avian influenza on US meat demand. J. Integr. Agr. 14, 1130-1141 (2015).

30. Zhou, L., Turvey, C. G., Hu, W. Y. \& Ying, R. Y. Fear and trust: how risk perceptions of avian influenza affect Chinese consumers' demand for chicken. China Econ. Rev. 40, 91-104 (2016).

31. Chiang, L. \& Sun, J. Impacts of African swine fever on China's feed industry and soy demand. Rabobank (April 2019); https://research.rabobank.com/far/ en/sectors/grains-oilseeds/ASF-China-Feed-and-Soy.html

32. Gilbert, M. et al. Income disparities and the global distribution of intensively farmed chicken and pigs. PLoS ONE 10, https://doi.org/10.1371/journal. pone.0133381 (2015).

33. Brown, V. R. \& Bevins, S. N. A review of African swine fever and the potential for introduction into the United States and the possibility of subsequent establishment in feral swine and native ticks. Front. Vet. Sci. 5 https://doi.org/10.3389/fvets.2018.00011 (2018).

34. Capua, I. \& Monti, M. African swine fever could splinter the EU. Nature 566 326-326 (2019).

35. World Development Indicators (World Bank, 2018).

36. McLeod, A., Morgan, N., Prakash, A. \& Hinrichs, J. Economic and Social impacts of Avian Influenza (FAO Emergency Centre for Transboundary Animal Diseases Operations, 2005).

37. Qiao, F. B., Huang, J. K., Wang, D., Liu, H. J. \& Lohmar, B. China's hog production: from backyard to large-scale. China Econ. Rev. 38, 199-208 (2016).
38. Rosegrant, M. W., Agcaoili-Sombilla, M. \& Perez, N. D. Global Food Projections to 2020: Implications for Investment (International Food Policy Research Institute, 1995).

39. Robinson, S. et al. The International Model for Policy Analysis of Agricultural Commodities and Trade (IMPACT): Model description for version 3 (IFPRI, 2015); http://ebrary.ifpri.org/cdm/ref/collection/p15738coll2/ $\mathrm{id} / 129825$

40. McDonald, S., Robinson, S. \& Thierfelder, K. GLOBE: A SAM Based Global CGE Model Using GTAP Data Departmental Working Papers 14 (United States Naval Academy Department of Economics, 2007).

41. Godfray, H. C. J., Mason-D’Croz, D. \& Robinson, S. Food system consequences of a fungal disease epidemic in a major crop. Phil. Trans. $R$. Soc. B 371, https://doi.org/10.1098/rstb.2015.0467 (2016).

42. Agricultural Policies in the Philippines (OECD, 2017).

43. Food System Shock: The Insurance Impacts of Acute Disruption to Global Food Supply (Lloyd's, 2015)

44. Springmann, M., Godfray, H. C. J., Rayner, M. \& Scarborough, P. Analysis and valuation of the health and climate change cobenefits of dietary change. Proc. Natl Acad. Sci. USA 113, 4146-4151 (2016).

45. Aguiar, A., Narayanan, B. \& McDougall, R. An overview of the GTAP 9 data base. J. Glob. Econ. Anal. 1, 181-208 (2016).

46. Willenbockel, D. et al. Dynamic Computable General Equilibrium Simulations in Support of Quantitative Foresight Modeling to Inform the CGIAR Research Portfolio: Linking the IMPACT and GLOBE models (IFPRI, 2018).

47. Gale, F., Marti, D. \& Hu, D. China's Volatile Pork Industry (USDA Economic Research Service, 2012).

48. Gale, F. \& Huang, K. Demand for Food Quantity and Quality in China 69-115 (USDA, 2010).

49. Chen, D. H., Abler, D., Zhou, D., Yu, X. H. \& Thompson, W. A meta-analysis of food demand elasticities for China. Appl. Econ. Perspect. Policy 38, 50-72 (2016).

\section{Acknowledgements}

H.C.J.G. and K.W. acknowledge support from the Wellcome Trust's Our Planet Our Health programme (205212/Z/16/Z); S.R., T.B.S. and K.W. from the CGIAR Research Program on Policies, Institutions, and Markets; and D.M.-D'C., J.R.B. and M.H. from the Australian Centre for International Agricultural Research (grant no. LS/2018/107, South East Asian Livestock Futures).

\section{Author contributions}

The project was conceived by H.C.J.G., S.R. and D.M.-D'C.; all authors contributed to its execution and write up with D.M.-D'C. leading on the IMPACT analysis, D.W. on the GLOBE analyses, J.R.B. on the nutrition aspects and H.C.J.G. and D.M.-D'C. on writing the paper.

\section{Competing interests}

The authors declare no competing interests.

\section{Additional information}

Supplementary information is available for this paper at https://doi.org/10.1038/ s43016-020-0057-2.

Correspondence and requests for materials should be addressed to D.M.-D C. Reprints and permissions information is available at www.nature.com/reprints. Publisher's note Springer Nature remains neutral with regard to jurisdictional claims in published maps and institutional affiliations.

(c) The Author(s), under exclusive licence to Springer Nature Limited 2020, corrected publication 2021 


\section{nature research}

Corresponding author(s): HCJ Godfray

Last updated by author(s): 2019-9-4

\section{Reporting Summary}

Nature Research wishes to improve the reproducibility of the work that we publish. This form provides structure for consistency and transparency in reporting. For further information on Nature Research policies, see Authors \& Referees and the Editorial Policy Checklist.

\section{Statistics}

For all statistical analyses, confirm that the following items are present in the figure legend, table legend, main text, or Methods section.

n/a Confirmed

Х $\square$ The exact sample size $(n)$ for each experimental group/condition, given as a discrete number and unit of measurement

\ $\square$ A statement on whether measurements were taken from distinct samples or whether the same sample was measured repeatedly

$\triangle$ The statistical test(s) used AND whether they are one- or two-sided

Х Only common tests should be described solely by name; describe more complex techniques in the Methods section.

Х $\square$ A description of all covariates tested

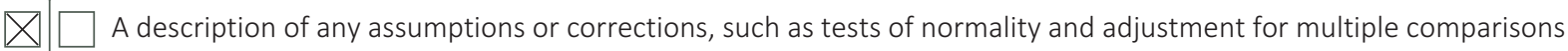

A full description of the statistical parameters including central tendency (e.g. means) or other basic estimates (e.g. regression coefficient)

$\triangle 1$ AND variation (e.g. standard deviation) or associated estimates of uncertainty (e.g. confidence intervals)

$\triangle$ For null hypothesis testing, the test statistic (e.g. $F, t, r$ ) with confidence intervals, effect sizes, degrees of freedom and $P$ value noted

$\triangle$ Give $P$ values as exact values whenever suitable.

Х $\square$ For Bayesian analysis, information on the choice of priors and Markov chain Monte Carlo settings

Х $\square$ For hierarchical and complex designs, identification of the appropriate level for tests and full reporting of outcomes

$\square \square$ Estimates of effect sizes (e.g. Cohen's $d$, Pearson's $r$ ), indicating how they were calculated

Our web collection on statistics for biologists contains articles on many of the points above.

\section{Software and code}

\section{Policy information about availability of computer code}

Data collection The IMPACT model (Robinson et al. 2015) was used to simulate the agricultural shocks of an outbreak of African Swine Fever in China on the global food system. GLOBE analysis: No software for data collection was required.

Data analysis GAMS (24.5.6) was used to run the models. MS Excel 365, and Tableau 2019.1 were used for analysis of the data. GLOBE analysis: The program GTAPAgg2.exe available to subscribers of the GTAP 9 database (https://www.gtap.agecon.purdue.edu/databases/default.asp) was used to generate the regional and sectoral aggregation of the GTAP 9 database employed in the present study. A full documentation of the GLOBE model version used is provided in Willenbockel, D et al (2018) Dynamic Computable General Equilibrium Simulations in Support of Quantitative Foresight Modeling to Inform the CGIAR Research Portfolio Linking the IMPACT and GLOBE Models. IFPRI Discussion Paper 01738.

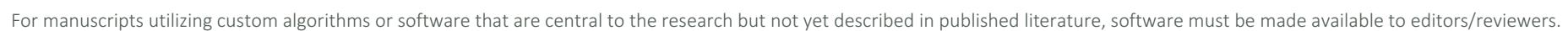
We strongly encourage code deposition in a community repository (e.g. GitHub). See the Nature Research guidelines for submitting code \& software for further information.

\section{Data}

Policy information about availability of data

All manuscripts must include a data availability statement. This statement should provide the following information, where applicable:

- Accession codes, unique identifiers, or web links for publicly available datasets

- A list of figures that have associated raw data

- A description of any restrictions on data availability

Data used in this analysis will be shared using Mendeley Data. Raw scenario results will be made available in the form of CSV or GDX files, and reported figures will be shared in Excel with underlying data.

- GLOBE is calibrated to the GTAP 9 database available at https://www.gtap.agecon.purdue.edu/databases/default.asp. Use of the database is restricted to license holders. 


\section{Field-specific reporting}

Please select the one below that is the best fit for your research. If you are not sure, read the appropriate sections before making your selection.
$\square$ Life sciences
\Behavioural \& social sciences
Ecological, evolutionary \& environmental sciences

For a reference copy of the document with all sections, see nature.com/documents/nr-reporting-summary-flat.pdf

\section{Behavioural \& social sciences study design}

All studies must disclose on these points even when the disclosure is negative.

Study description Scenario analysis using connected global economic models (IMPACT and GLOBE) to assess potential outcomes of African Swine Fever outbreak in China on the global food system

Research sample Models are built using national statistics from a range of available data sources from FAO, OECD, and GTAP.

Sampling strategy N/A

Data collection Data collection was based on secondary research and publically available online databases

Timing N/A

Data exclusions N/A

Non-participation N/A

Randomization N/A

\section{Reporting for specific materials, systems and methods}

We require information from authors about some types of materials, experimental systems and methods used in many studies. Here, indicate whether each material, system or method listed is relevant to your study. If you are not sure if a list item applies to your research, read the appropriate section before selecting a response.

\begin{tabular}{|c|c|}
\hline$n / a$ & Involved in the study \\
\hline$\bigotimes$ & $\square$ Antibodies \\
\hline$\bigotimes$ & Eukaryotic cell lines \\
\hline Х & Palaeontology \\
\hline$\bigotimes$ & Animals and other organisms \\
\hline$\bigotimes$ & $\square$ Human research participants \\
\hline$\bigotimes$ & $\square$ Clinical data \\
\hline
\end{tabular}

Methods

n/a Involved in the study

Х $\square$ ChIP-seq

Х $\square$ Flow cytometry

Х $\square$ MRI-based neuroimaging 